\title{
Irinotecan-Eluting Beads
}

National Cancer Institute

\section{Source}

National Cancer Institute. Irinotecan-Eluting Beads. NCI Thesaurus. Code C82682.

Microporous hydrospheres of polyvinylalcohol (PVA) impregnated with irinotecan with potential antineoplastic activity. In transarterial chemoembolization (TACE), irinotecaneluting beads are administered into blood vessels that feed the tumor, occluding tumor blood vessels and inducing ischemic tumor necrosis while simultaneously delivering highdose chemotherapy locally. Irinotecan, a semisynthetic derivative of camptothecin, inhibits topoisomerase I activity by stabilizing the cleavable complex between topoisomerase I and DNA, resulting in DNA breaks that inhibit DNA replication and trigger apoptotic cell death. 